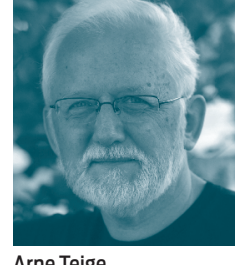

Arne Teige er psykiatrisk sykepleie ved Førde sentralsykehus.

I denne serien på 10 artikler gir han en grunnleggende innføring i de vanligste forskningsmetodene. Serien «Det metodiske hiørnet» skal sette leserne istand til kritisk å vurdere nyere forskning i sitt arbeid.

3 måter for å komme fram til et gjennomsnitt:

) Aritmetisk GJenNOMSNITT: hvor vi legger sammen alle målingene og deler på antallet

, Medianen: hvor vi rangordner målingene, og velger den midterste som gjennomsnitt

) Modalverdien: hvor vi velger den verdien som forekommer hyppigst

www.sykepleien.no

Les mer og finn litteraturhenvisninger på våre nettsider.

Søkeord:

) Evidensbasert

kunnskap

, Gjennomsnitt

\section{DE FLESTE KVINNER HAR TO BRYST.} Men siden noen ikke har det, er det aritmetiske gjennomsnittet lavere enn to.

eg vil forklare begrepene kort og poengtert, uten formler og matematikk, og benytter praktiske eksempler som alle kan vurdere. Jeg vil også angi de engelske begrepene, slik at det blir lettere å forstå og gjøre seg nytte av den internasjonale litteraturen. På sikt håper jeg at artiklene kan bidra til å øke den «evidensbaserte kunnskapen».

\section{Gjennomsnitt}

Gjennomsnitt er ett tall. Dette tallet er valgt som representant for ei gruppe tall som alle beskriver en tilstand eller egenskap - f eks «antall bryst hos voksne norske kvinner». Individene i gruppa vil ha ulikt antall bryst. Gjennomsnittsverdien er det tallet som best beskriver gruppa og tilstanden/egenskapen.

For å finne gjennomsnittsverdien, må vi enten telle eller måle. Dette enkle forholdet inneholder mange metodiske problemstillinger. Hva teller eller måler vi? (I eksemplet: Teller et «rekonstruert bryst» som et bryst?) Hva er måleinstrumentet? Hvordan standardiserer vi målingene? Hvor mye måler vi feil? Hvor mange må vi måle, for å være noenlunde sikre på gjennomsnittsverdien? Hvordan må vi velge forsøkspersoner for å være sikre på at de er representative for gruppa «norske kvinner»? Slike spørsmål vil jeg belyse etter hvert.

\section{Forskjellige typer gjennomsnitt} Når vi måler noe, sammenligner vi. Måler vi høyden på skolebarn, sammenligner vi høyden til hvert barn med et metermål. Vi angir dette som Aud's høyde $=1,17$ meter.

Vi kan sammenligne ved å legge sammen høydene til alle barna, og

\section{i.}

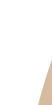

\title{
De fleste norske kvinner har flere bryst enn gjennomsnittet
}

Hvordan vurderer man «evidensbasert kunnskap»? Dette spørsmålet vil jeg svare på i denne serien. Jeg vil beskrive vanlige statistiske begreper og metoder, vise hvordan metodene benyttes, og hvordan forskningsresultat sammenfattes for å skape «evidensbasert kunnskap».

deretter dele summen på antall barn. Det tallet vi da får, kalles aritmetisk gjennomsnitt (på engelsk «mean»), «aritmetisk» fordi vi har «regna ut» verdien. Vi kan da for eksempel si at Aud er $4 \mathrm{~cm}$ lavere enn gjennomsnittet i klassen.

Vi kan sammenligne på andre måter. Vi kan ordne alle barna i ei rekke, fra den laveste til den høyeste. Dersom Aud er midt i rekka, kan vi velge Aud sin høyde som gjennomsnittsverdi. Aud vil da ha like mange barn på hver side. En slik gjennomsnittsverdi kalles median (på engelsk «median»).

Her hvor jeg bor finnes fire dagligvarebutikker. Tre av disse hører til samme kjede, en butikk er uavhengig. I alle kjedebutikkene koster eplene 12.95 pr. kilo, hos den uavhengige kr 11.95. Jeg kan velge den verdien som hyppigst forekommer, som gjennomsnittsverdi, i eksempelet kr 12.95. Et slikt gjennomsnitt kalles modalverdien (på engelsk «mode»).

\section{Sammendrag}

Vi kan telle

eller måle en til-

-

stand eller en egenskap. Å måle noe er å sammenligne med noe annet.

Det vi sammenligner med, kan være kjente og standardiserte «mål», som en meter. Eller det kan være en skala, for eksempel «Apgar-skåre».

Et gjennomsnitt" er ett tall som «best sammenfatter» disse målingene eller tellingene. Jeg har beskrevet tre typer.

> ARITMETISK GJENNOMSNItT: hvor vi legger sammen alle målingene og deler på antallet

I Medianen: hvor vi rangordner målingene, og velger den midterste som gjennomsnitt

I Modalverdien: hvor vi velger den verdien som forekommer hyppigst

Som alt annet, har hver sine fordeler og ulemper. Det kommer jeg tilbake til.

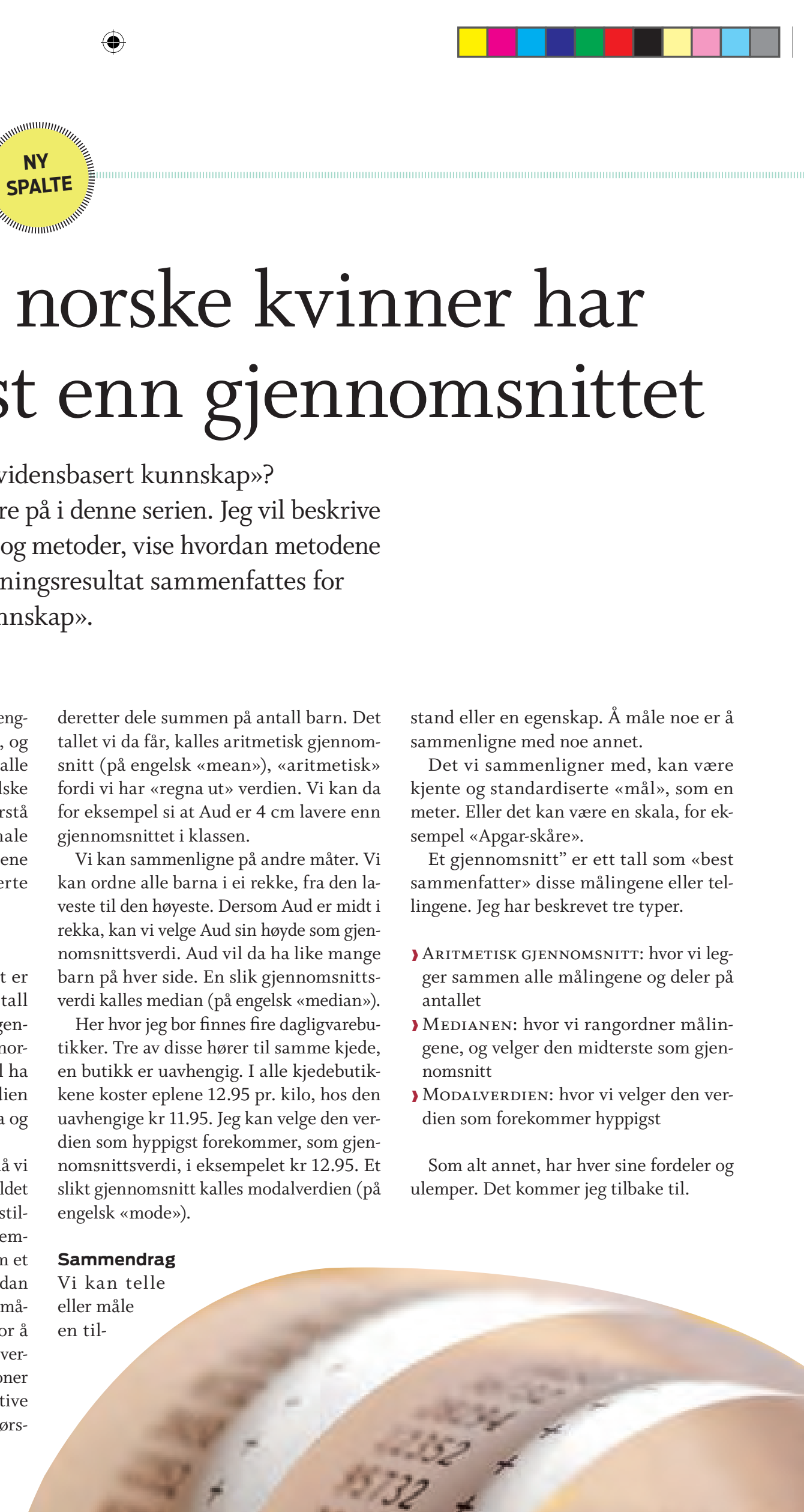

